\title{
A Ca 3.2 T-Type Calcium Channel Point Mutation Has Splice-Variant-Specific Effects on Function and Segregates with Seizure Expression in a Polygenic Rat Model of Absence Epilepsy
}

\author{
Kim L. Powell, ${ }^{1 \star}$ Stuart M. Cain, ${ }^{2 \star}$ Caroline Ng, ${ }^{1}$ Shreerang Sirdesai, ${ }^{1}$ Laurence S. David, ${ }^{2}$ Mervyn Kyi, ${ }^{1}$ \\ Esperanza Garcia, ${ }^{2}$ John R. Tyson, ${ }^{2}$ Christopher A. Reid, ${ }^{3}$ Melanie Bahlo, ${ }^{4}$ Simon J. Foote, ${ }^{5}$ Terrance P. Snutch, ${ }^{2}$ and \\ Terence J. O'Brien ${ }^{1}$ \\ ${ }^{1}$ Departments of Medicine, Surgery, and Neurology, The Royal Melbourne Hospital, University of Melbourne, Melbourne, Victoria 3050, Australia, ${ }^{2}$ Michael \\ Smith Laboratories, University of British Columbia, Vancouver, British Columbia, Canada V6T 1Z4, ${ }^{3}$ Howard Florey Institute, University of Melbourne, \\ Melbourne, Victoria 3010, Australia, ${ }^{4}$ The Walter and Eliza Hall Institute of Medical Research, Melbourne, Victoria 3050, Australia, and ${ }^{5}$ Menzies Research \\ Institute, University of Tasmania, Hobart, Tasmania 7000, Australia
}

Low-voltage-activated, or T-type, calcium $\left(\mathrm{Ca}^{2+}\right)$ channels are believed to play an essential role in the generation of absence seizures in the idiopathic generalized epilepsies (IGEs). We describe a homozygous, missense, single nucleotide (G to $\mathrm{C}$ ) mutation in the $\mathrm{Ca}_{\mathrm{v}} 3.2$ T-type $\mathrm{Ca}^{2+}$ channel gene (Cacnalh) in the genetic absence epilepsy rats from Strasbourg (GAERS) model of IGE. The GAERS Ca $\mathrm{v}_{\mathrm{v}} 3.2$ mutation $(\mathrm{gcm})$ produces an arginine to proline (R1584P) substitution in exon 24 of Cacnalh, encoding a portion of the III-IV linker region in $\mathrm{Ca}_{\mathrm{v}}$ 3.2. $\mathrm{gcm}$ segregates codominantly with the number of seizures and time in seizure activity in progeny of an $\mathrm{F} 1$ intercross. We have further identified two major thalamic Cacna $\mathrm{h}$ splice variants, either with or without exon $25 . \mathrm{gcm}$ introduced into the splice variants acts "epistatically," requiring the presence of exon 25 to produce significantly faster recovery from channel inactivation and greater charge transference during high-frequency bursts. This gain-of-function mutation, the first reported in the GAERS polygenic animal model, has a novel mechanism of action, being dependent on exonic splicing for its functional consequences to be expressed.

Key words: idiopathic generalized epilepsy; absence seizures; T-type calcium channel; splice variant; point mutation; genetic absence epilepsy rats from Strasbourg; GAERS

\section{Introduction}

The idiopathic generalized epilepsies (IGEs) are a common group of diseases with a strong hereditary component. Despite a small number of genes explaining the disease in rare families, the genetic causes of the majority of the IGEs remain undetermined and are generally believed to be polygenic. Absence seizures, which form part of the IGE spectrum, are nonconvulsive generalized seizures resulting in a brief impairment of consciousness (Mattson, 2003). The genetic absence epilepsy rats from Strasbourg (GAERS) are a well validated genetic rat model of absence

\footnotetext{
Received Nov. 3, 2008; accepted Nov. 20, 2008.

This work was supported by National Health and Medical Research Council Grants 406640 (T.J.O., S.J.F.) and 454655 (C.A.R.), the Molly MCDonnell Foundation Scholarship (K.L.P.), and Canadian Institutes of Health Research Grant 10677 (T.P.S.). T.P.S. is a Tier 1 Canada Research Chair in Biotechnology and Genomics-Neurobiology.

*K.L.P. and S.M.C. contributed equally to this work.

Correspondence should be addressed to either of the following: Terence $0^{\prime} B r i e n$, Department of Medicine (Royal Melbourne Hospital/Western Hospital), The University of Melbourne, 4th Floor, Clinical Sciences Building, Royal Melbourne Hospital, Royal Parade, Parkville, Victoria 3050, Australia, E-mail: obrientj@unimelb.edu.au; or Terrance Snutch, Michael Smith Laboratories, The University of British Columbia, 301-2185 East Mall, Vancouver, British Columbia, Canada V6T 1Z4, E-mail: snutch@msl.ubc.ca.

DOI:10.1523/JNEUROSCI.5295-08.2009

Copyright $\odot 2009$ Society for Neuroscience $\quad$ 0270-6474/09/290371-10\$15.00/0
}

epilepsy (Marescaux et al., 1984) that exhibit spontaneous spikeand-wave discharges (SWDs) on a normal electroencephalogram (EEG) background, closely resembling the human condition. Cross-breeding (Marescaux et al., 1992) and qualitative trait linkage analysis (Rudolf et al., 2004) studies indicate that the epilepsy phenotype in GAERS is polygenically determined. However, despite two decades of study, the nature of the genetic determinants underlying the epileptic phenotype of GAERS has not been identified previously.

The thalamocortical network is critically involved in the propagation of SWDs in both human absence epilepsy and many animal models (Crunelli and Leresche, 2002). Extensive investigation has revealed that neuronal low-voltage-activated (T-type) $\mathrm{Ca}^{2+}$ channels underlie burst firing and oscillatory behavior in this network as a result of their ability to generate $\mathrm{Ca}^{2+}$ spikes near resting membrane potential (Llinas and Yarom, 1981; Carbone and Lux, 1984; Huguenard and Prince, 1992; Perez-Reyes, 2003). Three lines of evidence specifically implicate the T-type $\mathrm{Ca}^{2+}$ channel with absence epilepsy. First, $\mathrm{Ca}_{\mathrm{v}} 3.2$ mRNA expression (Talley et al., 2000) and T-type $\mathrm{Ca}^{2+}$ currents (Tsakiridou et al., 1995) have been found to be elevated in the reticular nucleus of the thalamus (nRT) of GAERS. Second, elevated thalamic 
T-type currents precede the onset of absence seizures in a SNAP-25-deficient mouse model (Zhang et al., 2004). Third, mutations in the human CACNA1H have been found in patients with childhood absence epilepsy and juvenile absence epilepsy (Chen et al., 2003; Liang et al., 2006, 2007; Heron et al., 2007) with exogenous expression of mutant human $\mathrm{Ca}_{\mathrm{v}} 3.2$ channels revealing a variety of biophysical changes (Khosravani et al., 2004, 2005; Vitko et al., 2005, 2007; Peloquin et al., 2006).

Here we report the first mutation with functional effects in a polygenic animal model of absence epilepsy. The GAERS $\mathrm{Ca}_{\mathrm{v}} 3.2$ mutation $(\mathrm{gcm})$ is situated in exon 24 of Cacnalh in a region encoding a portion of the domain III-IV linker. Electrophysiological investigation revealed that $\mathrm{gcm}$ increases the rate of recovery from channel inactivation, producing a predicted gainof-function phenotype. The functional effects of $\mathrm{gcm}$ are dependent on alternative splicing of exon 25 , being manifested in the splice variant with this exon $\left[\mathrm{Ca}_{\mathrm{v}} 3.2(+25)\right]$. These results provide unique insight into the genetic cause of absence seizures in GAERS as well as provide new knowledge regarding the structural-functional relationship for $\mathrm{Ca}_{\mathrm{v}} 3.2 \mathrm{~T}$-type $\mathrm{Ca}^{2+}$ channels. Of particular importance is the demonstration of the principle that genetic mutations may have functional effects only in certain splice variants of ion channels (Adams et al., 2007).

\section{Materials and Methods}

Production of F2 generation. The double cross matings required for this study were produced in two stages. First, GAERS rats (homozygous or $-/$ - for the $\mathrm{Ca}_{\mathrm{v}} 3.2 \mathrm{gcm}$ mutation) were crossed with nonepileptic control (NEC) rats (null or $+/+$ for the $g c m$ mutation) to produce an F1 generation, all of which should be heterozygous for the mutation. Then, two F1 (+/-) generation rats were mated to produce an F2 generation. On average, $25 \%$ of the $\mathrm{F} 2$ progeny would be expected to be homozygous for the mutation, $50 \%$ heterozygous for the mutation, and $25 \%$ null or not carrying the mutation at all.

Animal surgeries. The study was approved by the Animal Ethics Committee of the Ludwig Institute for Cancer Research/Department of Surgery, The Royal Melbourne Hospital, The University of Melbourne and conformed to National Health and Medical Research Council guidelines for the ethical use of animals in scientific research. All surgeries were performed under deep general anesthetic, with each rat receiving an intraperitoneal injection $(5 \mathrm{ml} / \mathrm{kg})$ of anesthetic solution containing ketamine (75 mg/kg; Ketavet 100; Parnell Laboratories) and xylazine (10 $\mathrm{mg} / \mathrm{kg}$; Xylazil-20; Troy Laboratories) in $0.9 \%$ sodium chloride. Once anesthetized, a single midline incision was made on the scalp, from just posterior to the eyes to between the ears. Six holes were drilled through the skull but not penetrating the dura, one on each side anterior to the bregma and two on each side posterior to the bregma. A recording electrode was screwed into each hole. Each recording electrode comprised a $1.3 \mathrm{~mm}$ "male" gold connector (Farnell Components) soldered onto a nickel alloy jeweler screw. The recording electrodes were fixed in position by applying Vertex dental cement around the electrodes and over the skull. The incision was then sutured (Dysilk 3/0). Immediately after surgery, each rat received an intraperitoneal injection of $1 \mathrm{ml} / \mathrm{kg}$ analgesic solution containing intraperitoneal carprofen analgesic ( $5 \mathrm{mg} / \mathrm{kg}$; Rimadyl; Pfizer Australia) in $0.9 \%$ sodium chloride. Polyvisc was again applied to the eyes.

EEG recordings and analysis. Seven days after surgery, all rats underwent four 90 min EEG recordings over weeks 17 and 18 (two recordings per week). The rats were connected to an EEG board, and their EEG trace was recorded using Compumedics EEG acquisition software. Recordings lasted $90 \mathrm{~min}$ after an initial $15 \mathrm{~min}$ habituation period. Recordings alternately took place in the morning or afternoon; each rat had two morning and two afternoon recordings. The animals were able to move freely around their cage and were constantly monitored by an investigator to ensure that they did not fall asleep using gentle finger taps on the side of the cage as necessary. Rats were allowed at least $2 \mathrm{~d}$ rest between consecutive recordings. All rats were observed during the recording to confirm their seizure status. Seizure expression for the $90 \mathrm{~min}$ after injection EEG recording was quantified by visual inspection of the EEG recordings, blinded to the animal's genotype. Standard criteria described for adult GAERS were used to classify the seizures, i.e., an SWD burst of amplitude of more than three times baseline, a frequency of 7-12 Hz, and duration of longer than $0.5 \mathrm{~s}$ (Marescaux et al., 1992; Liu et al., 2006). The start and end of each seizure was determined by manually marking the beginning and end of each SWD on the EEG. From this, the total percentage time spent in seizure over the 90 min postinjection EEG recording was determined, the primary endpoint for comparison of the treatment effect on seizure expression.

Genomic DNA extraction and genotyping PCR. Genomic DNA was extracted from tail tips using the Promega Wizard Genomic DNA extraction kit, and genotyping PCR was performed using primers designed to amplify exon 24 (193 bp). Each $20 \mu \mathrm{l}$ of PCR reaction contained the following: $1 \times$ TaqDNA polymerase buffer, $2.5 \mathrm{U}$ of TaqDNA polymerase, $250 \mu \mathrm{M}$ dNTPs, $500 \mathrm{~nm}$ forward and reverse primers, and $25 \mathrm{ng}$ of genomic DNA (for primer sequences, see supplemental Table 1, available at www.jneurosci.org as supplemental material). To confirm the correct size band, $5 \mu$ l of PCR reactions were run on a $2 \%$ agarose gel with molecular weight markers, and gels were stained with GelRed DNA stain (Jomar) and visualized under UV light. PCR reactions were cleaned up using the Promega PCR cleanup kit, and purified PCR products were sent to the Australian Genome Research Facility (Brisbane, Australia) for sequencing (for primer sequences, see supplemental Table 1, available at www.jneurosci.org as supplemental material). Sequence analysis was done using Sequence Scanner version 1.0 (Applied Biosystems).

RNA extraction and cDNA synthesis. Total RNA was extracted from adult Wistar rat thalamus using Trizol reagent (Invitrogen) according to the instructions of the manufacturer. One microgram total RNA was initially treated with DNase to avoid genomic DNA contamination during reverse transcription using the Superscript II reverse transcriptase (Invitrogen) enzyme. A total of $20 \mu \mathrm{l}$ of reaction volume was prepared containing DNase-treated total RNA, first strand buffer $(1 \times)$, DTT (10 $\mu \mathrm{M})$, oligo-dT $(0.5 \mu \mathrm{g} / \mathrm{L})$, dNTP mix $(500 \mu \mathrm{M})$, RNAseOUT (40 U), and reverse transcriptase $(200 \mathrm{U})$. Reaction mixture was incubated at $42^{\circ} \mathrm{C}$ for $50 \mathrm{~min}$ and inactivated by heating to $70^{\circ} \mathrm{C}$ for $15 \mathrm{~min}$. Finally, RNase $\mathrm{H}(2 \mathrm{U})$ was added to the mixture and incubated at $37^{\circ} \mathrm{C}$ for $20 \mathrm{~min}$ to remove the RNA complementary to the cDNA.

Splice variant screening, cloning, and site-directed mutagenesis. Initially, 

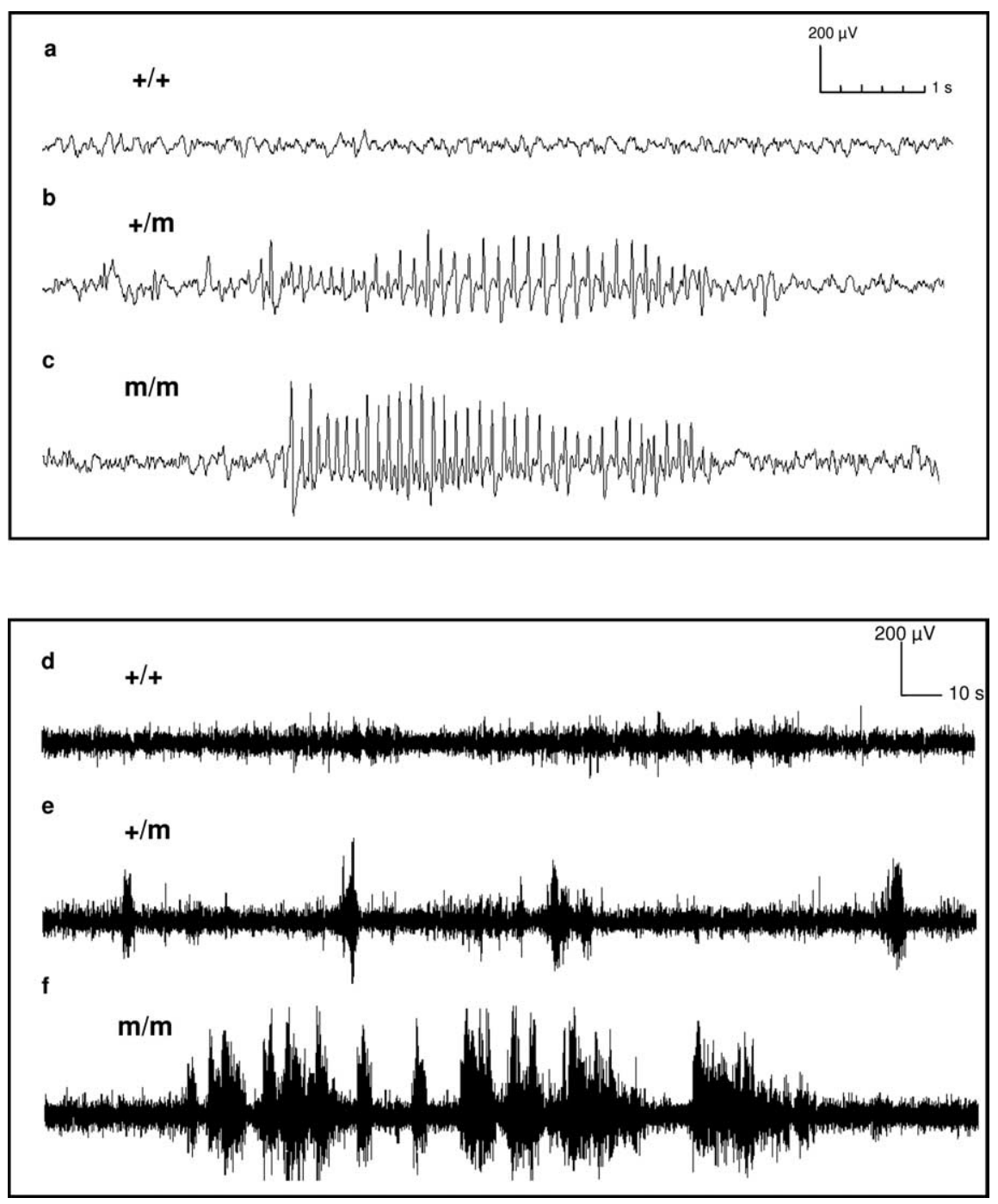

Figure 1. Representative EEG traces from $\mathrm{m} / \mathrm{m}(\boldsymbol{a}, \boldsymbol{d}),+/ \mathrm{m}(\boldsymbol{b}, \boldsymbol{e})$, and $\mathrm{m} / \mathrm{m}(\boldsymbol{c}, \boldsymbol{f})$ animals over a 10 s period $(\boldsymbol{a}-\boldsymbol{c})$ and a $5 \mathrm{~min}$ period $(\boldsymbol{d}-\boldsymbol{f}) .+1+$ animals are null for the R1584P mutation $(\mathrm{gcm}),+/ \mathrm{m}$ animals carry one copy of the mutation, and $\mathrm{m} / \mathrm{m}$ animals are homozygous for the $\mathrm{gcm}$ mutation.

splice variant exon scanning was performed on rat thalamic RNA to identify the existence of expressed $\mathrm{Ca}_{\mathrm{v}} 3.2$ isoforms. Overlapping primer sets were designed to amplify between two and five exons. PCR products were sequenced and compared with genomic sequence for the presence of splice sites. Subsequently, full-length $\mathrm{Ca}_{\mathrm{v}} 3.2 \mathrm{cDNA}$ libraries were made from thalamic total RNA $(2 \mu \mathrm{g})$ using $\mathrm{Ca}_{\mathrm{v}} 3.2$-specific forward $\left(5^{\prime}\right.$-GATAAGCTTATGACCGAGGGCACG-3 $\left.{ }^{\prime}\right)$ and reverse $\left(5^{\prime}\right.$ CGCTCTAGACTACACAGGCTCATC- $3^{\prime}$ ) primers. The cDNA products were subcloned into the pGEM T-Easy vector (Promega), and a total of 76 full-length $\mathrm{Ca}_{\mathrm{v}} 3.2 \mathrm{cDNAs}$ were subject to complete DNA sequencing. Full-length $\mathrm{Ca}_{\mathrm{v}} 3.2$ with or without exon 25 alternative splice variants were moved from pGEM T-Easy to pCDNA3.1 zeo(+) (Invitrogen) using the restriction enzymes HindIII and $\mathrm{XbaI}$ (introduced at beginning and end, respectively, of the $\mathrm{Ca}_{\mathrm{v}} 3.2 \mathrm{cDNAs}$ ). The DNA sequence of the full-length $\mathrm{Ca}_{\mathrm{v}} 3.2$ clones were determined using automated DNA sequencing, and sequences were aligned to available published genomic $\mathrm{Ca}_{\mathrm{v}} 3.2$ sequences. The $\mathrm{gcm}$ was introduced into the $+/-$ exon $25 \mathrm{Ca}_{\mathrm{v}} 3.2$ clones using the Quickchange site-directed mutagenesis (SDM) procedure (Stratagene) with the GAERS-sdm 1 (5' -AGGAGGCTCGGCGCCCGGAGGAGAAACGGCT-3') and GAERS-sdm2 (5'-AGCCGTTTCTCCTCCGGGCGCCGAGCCTCCT-3') primers. Once generated, the GAERS mutation $+/-$ exon 25 was removed as an 872 bp EcoRV-BstBI fragment and cloned back into a nonmutagenized $\mathrm{Ca}_{\mathrm{v}} 3.2$ plasmid background to remove nonspecific mutations introduced during SDM. Fi- nally, the \pm exon 25 GAERS clones were then fully resequenced to confirm that no other mutation had been introduced.

Tissue collection. Adult chronically epileptic (18-21 weeks) GAERS and age-matched NEC rats were culled by a lethal dose of pentobarbital (Lethabarb) anesthetic (Virbac), followed by rapid extraction of the brain. The thalamic brain region was rapidly dissected and stored in RNALater (Applied Biosystems) and frozen at $-80^{\circ} \mathrm{C}$.

Quantitative real-time-PCR. RNA was extracted using the RNeasy mini kit (QIAGEN) and treated with DNase I (QIAGEN) to remove any contaminating genomic DNA and stored at $-80^{\circ} \mathrm{C}$. Spectrophotometric readings were taken with the NanoDrop Spectrophotometer (NanoDrop Technologies) to determine RNA concentration and purity. For each sample, 2 $\mu \mathrm{g}$ of total RNA was used to synthesize cDNA using the High Capacity cDNA Reverse Transcription kit from Applied Biosystems. Realtime-PCR reaction was performed using Applied Biosystems reagents and TaqMan probes to the respective gene targets on an Applied Biosystems AB 7500 system. Primer mixes used for detection of exon 25 splice variants were as follows: + exon 25 ( $\mathrm{H}-\mathrm{Ca}_{\mathrm{v}} 3.2$-plus 25 forward, GCGCAGGAGCACTTTCC; H-Ca 3.2-plus25 reverse, GAGTGTGTGAATAGTCTGCGTAGTA; $\mathrm{H}_{-\mathrm{Ca}_{\mathrm{v}} 3}$ 3.2-plus25-Probe, CCAACCCAGAGGCCCAG); - exon $25\left(\mathrm{H}-\mathrm{Ca}_{\mathrm{v}} 3.2-\right.$ minus 25 forward, CGCCGGGAGGAGAAACG; H-Ca 3 3.2-minus25 reverse, GAGTGTGTGAATAGTCTGCGTAGTA; $\mathrm{H}-\mathrm{Ca}_{\mathrm{v}} 3.2-$ minus25-Probe, CTGGGCCTTCCTGCGCC). Titration curves to calculate copy number parameters for each of the + and - exon 25 primer sets were produced using splice-variantspecific full-length cDNA plasmid clones. A rat actin B (ActB) primer set (Applied Biosystems $\mathrm{AB} 4352340 \mathrm{E})$ was run in parallel with the + and - exon 25 probes in all samples as a control for total cDNA input to allow comparison. Copy numbers for each splice variant in each sample were then calculated and scaled, using relative ActB amounts, before being compared. Target and control probe reactions were run in triplicate and averaged for each sample.

Cell culture. Human embryonic kidney (HEK) 293 cells were grown at $37^{\circ} \mathrm{C}$ in DMEM supplemented with $10 \%$ heat-inactivated FBS, $50 \mathrm{U} / \mathrm{ml}$ penicillin, and $50 \mu \mathrm{g} / \mathrm{ml}$ streptomycin. Cells were transiently transfected with $\mathrm{Ca}_{\mathrm{v}} 3.2$ or $\mathrm{Ca}_{\mathrm{v}} 3.2 \mathrm{gcm}\left(0.6 \mu \mathrm{g}\right.$ of cDNA per $35 \mathrm{~mm}^{2}$ dish, plus $0.1 \mu \mathrm{g}$ per dish of GFP marker) in pcDNA3.1zeo $(+)$ using Lipofectamine (Invitrogen). Cells were incubated at $37^{\circ} \mathrm{C}$ in a humidified incubator with $5 \% \mathrm{CO}_{2}$ for $24-48 \mathrm{~h}$ before recording.

Electrophysiology. $\mathrm{Ca}^{2+}$ currents were recorded using the whole-cell patch-clamp technique with the following two solutions (in $\mathrm{mM}$ ): internal: 120 Cs-methanesulphonate, 11 EGTA, 10 HEPES, $2 \mathrm{MgCl}_{2}, 5$ MgATP, and 0.3 NaGTP, pH 7.2; external: $2 \mathrm{CaCl}_{2}, 1 \mathrm{MgCl}_{2}, 10$ HEPES, 40 tetraethylammonium- $\mathrm{Cl}, 92 \mathrm{CsCl}$, and 10 glucose, $\mathrm{pH}$ 7.4. Firepolished patch pipettes (borosilicate glass) had typical resistances of 3-5 $\mathrm{M} \Omega$ when containing internal solution. The recording chamber was grounded with an $\mathrm{Ag} / \mathrm{AgCl}$ pellet. Whole-cell currents were recorded at room temperature using an Axopatch 200B amplifier (Molecular Devices). Data were acquired with pClamp software package version 9 (Molecular Devices). Series resistance $\left(R_{\mathrm{s}}\right)$ was compensated by $65-75 \%$, and seals with $R_{\mathrm{s}}$ values $>20 \mathrm{M} \Omega$ or cells with peak current $<100$ pA were discarded. Data analysis was performed using Clampfit 9 (Molecular Devices) and software Origin version 7.5 (Microcal Software). Data fol- 
lowed a normal distribution, and statistical significance was calculated using one-way ANOVA with Tukey's post hoc test considering a $p$ value $<0.05$ as significant. Data were plotted as mean \pm SE values.

The current-voltage $(I-V)$ relationship was obtained by depolarizing the membrane with $150 \mathrm{~ms}$ pulses from a holding potential of -110 $\mathrm{mV}$ (currents sampled at $10 \mathrm{kHz}$ and filtered at $2 \mathrm{kHz}$ ). Test pulses from -90 to $+10 \mathrm{mV}$ were applied at $5 \mathrm{mV}$ steps. Peak amplitude of $\mathrm{Ca}^{2+}$ currents was plotted against test pulse potential, and $I-V$ curves were fitted using a modified Boltzmann equation: $I=\left(G_{\max }{ }^{*}\left(V_{\mathrm{m}}-E_{\mathrm{r}}\right)\right) /(1$ $\left.+\exp \left(\left(V_{\mathrm{m}}-V_{50}\right) / k\right)\right)$, where $G_{\max }$ is the maximum value of membrane conductance, $V_{\mathrm{m}}$ is the test potential, $E_{\mathrm{r}}$ is the extrapolated reversal potential, $V_{50}$ is the half-activation potential, and $k$ (slope constant: $k=R T / z \delta F$, where $r$ is gas constant, $T$ is absolute temperature, $z$ is valence of conducting ion, $\delta$ is electrical distance across the membrane, and $F$ is Faraday's constant) reflects the voltage sensitivity. Activation curves were obtained by calculating conductance from the $I-V$ curves and plotting the normalized conductance as a function of the membrane potential. The data were fitted with the following Boltzmann equation: $G / G_{\max }=A_{2}+\left(A_{1}-\right.$ $\left.A_{2}\right) /\left(1+\exp \left(\left(V_{\mathrm{m}}-V_{50}\right) / k\right)\right)$, where $A_{1}$ is minimum normalized conductance, $A_{2}$ is maximum normalized conductance, $V_{\mathrm{m}}$ is the test potential, $V_{50}$ is the half-activation potential, and $k$ value is the slope of the activation curve (slope constant).

Steady-state inactivation was studied using $90 \mathrm{~ms}$ test pulses at $-30 \mathrm{mV}$ applied after $2 \mathrm{~s}$ conditioning prepulses ranging from -120 to $-10 \mathrm{mV}$ (currents sampled at $10 \mathrm{kHz}$ and filtered at $2 \mathrm{kHz}$ ). The current magnitude obtained during each test pulse was normalized to the maximum at $-120 \mathrm{mV}$ and plotted as a function of the prepulse potential. The data were fitted with the following Boltzmann equation: $I / I_{\max }=A_{2}+\left(A_{1}-A_{2}\right) /\left(1+\exp \left(\left(V_{\mathrm{m}}-\right.\right.\right.$ $\left.\left.V_{50}\right) / k\right)$ ), where $A_{1}$ is minimum normalized current, $A_{2}$ is the maximum normalized current, $V_{\mathrm{m}}$ is the test potential, $V_{50}$ is the halfinactivation potential, and $k$ reflects the slope of the inactivation curve (slope constant). The time course for activation $\left(\tau_{\text {act }}\right)$ and inactivation $\left(\tau_{\text {inact }}\right)$ were analyzed by fitting current recordings obtained from the $I-V$ protocol with a single-exponential standard equation: $I=A e-$ $t / \tau$, where $A$ is the amplitude of the current, and $\tau$ is the time constant.

Recovery from inactivation was studied using a double-pulse protocol at a holding potential of $-110 \mathrm{mV}$ (currents sampled at $2 \mathrm{kHz}$ and filtered at $2 \mathrm{kHz}$ ) to ensure complete deinactivation of $\mathrm{Ca}_{\mathrm{v}} 3.2$ channels. The cell membrane was depolarized for $400 \mathrm{~ms}$ to $-30 \mathrm{mV}$ (prepulse) to ensure complete channel inactivation and then to $-30 \mathrm{mV}$ for $50 \mathrm{~ms}$ (test pulse) after an increasing time period (interpulse interval) between $5 \mathrm{~ms}$ and $5 \mathrm{~s}$. The peak current from the test pulse was plotted as a ratio of maximum prepulse current versus interpulse interval. The data were fitted with a double-exponential function: $I / I_{\max }=A 1 * \exp \left(-t / \tau_{1}\right)+A_{2} * \exp (-t /$ $\tau_{2}$ ), where $A_{1}$ and $A_{2}$ are the amplitude for the fast and slow components of the exponential, and $\tau_{1}$ and $\tau_{2}$ are the time constants for the fast and slow components, respectively.
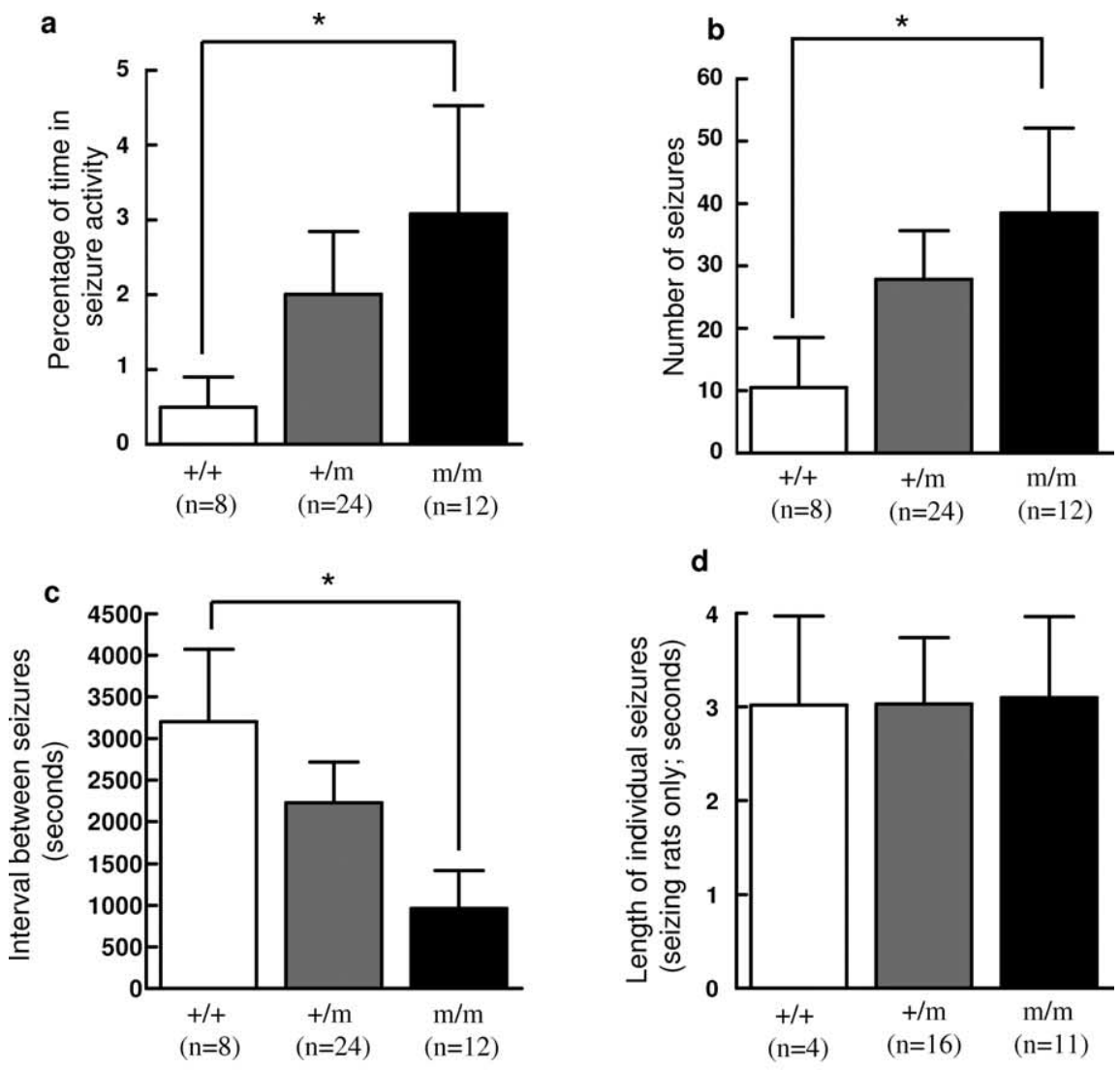

e

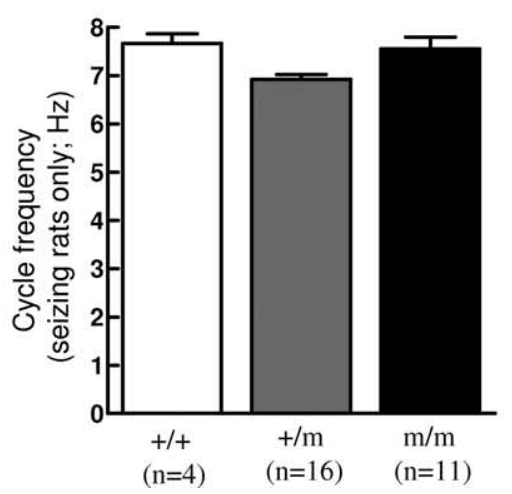

Figure 2. The gcm mutation positively correlates with the epileptic phenotype in double-crossed (F2) GAERS versus NEC rats. $\boldsymbol{a}$, Percentage of recording time spent in seizure activity. Animals homozygous for the mutation spend more time in seizure activity than animals null for the $g \mathrm{~cm}(p<0.05$, Mann-Whitney one-tailed test). $\boldsymbol{b}$, Number of seizures. Animals homozygous for the $g \mathrm{~cm}$ experience more seizures than animals null for the mutation ( $p<0.05$, Mann-Whitney one-tailed test). $\boldsymbol{c}$, The interval between the seizures was significantly shorter for animals homozygous for the mutation compared with animals null for the mutation ( $p<0.05$, Mann-Whitney one-tailed test). $\boldsymbol{d}$, The length of individual seizures did not significantly differ between the genotypes ( $p>0.05$, Mann-Whitney one-tailed test). $e$, The cycle frequency of the spike-and-wave discharges (hertz) did not significantly differ between the genotypes ( $p>0.05$, Mann-Whitney one-tailed test). $+/+$ animals are null for the $g \mathrm{~cm},+/ \mathrm{m}$ animals have one copy of the $g \mathrm{~cm}$, and $\mathrm{m} / \mathrm{m}$ animals are homozygous for the $\mathrm{gcm}$. Data are expressed as mean $\pm \mathrm{SEM} .{ }^{*} p<0.05$.
$\mathrm{Ca}_{\mathrm{v}} 3.2$ activity during high-frequency burst depolarization was studied using a burst square pulse protocol at a holding potential of $-70 \mathrm{mV}$ (currents sampled at $10 \mathrm{kHz}$ and filtered at $5 \mathrm{kHz}$ ). The membrane was depolarized for $4 \mathrm{~ms}$ to $-20 \mathrm{mV}$ at a frequency of $125 \mathrm{~Hz}$ for $80 \mathrm{~ms}$ to produce a high-frequency burst. Burst depolarizations were performed at a frequency of $5 \mathrm{~Hz}$ for $1 \mathrm{~s}$. The data were analyzed by taking the integral of each burst individually giving a measurement of charge transference $(Q)$ carried by $\mathrm{Ca}^{2+}$ through $\mathrm{Ca}_{\mathrm{v}} 3$.2. Charge transference was then divided by the peak current on the first pulse of the first burst to 


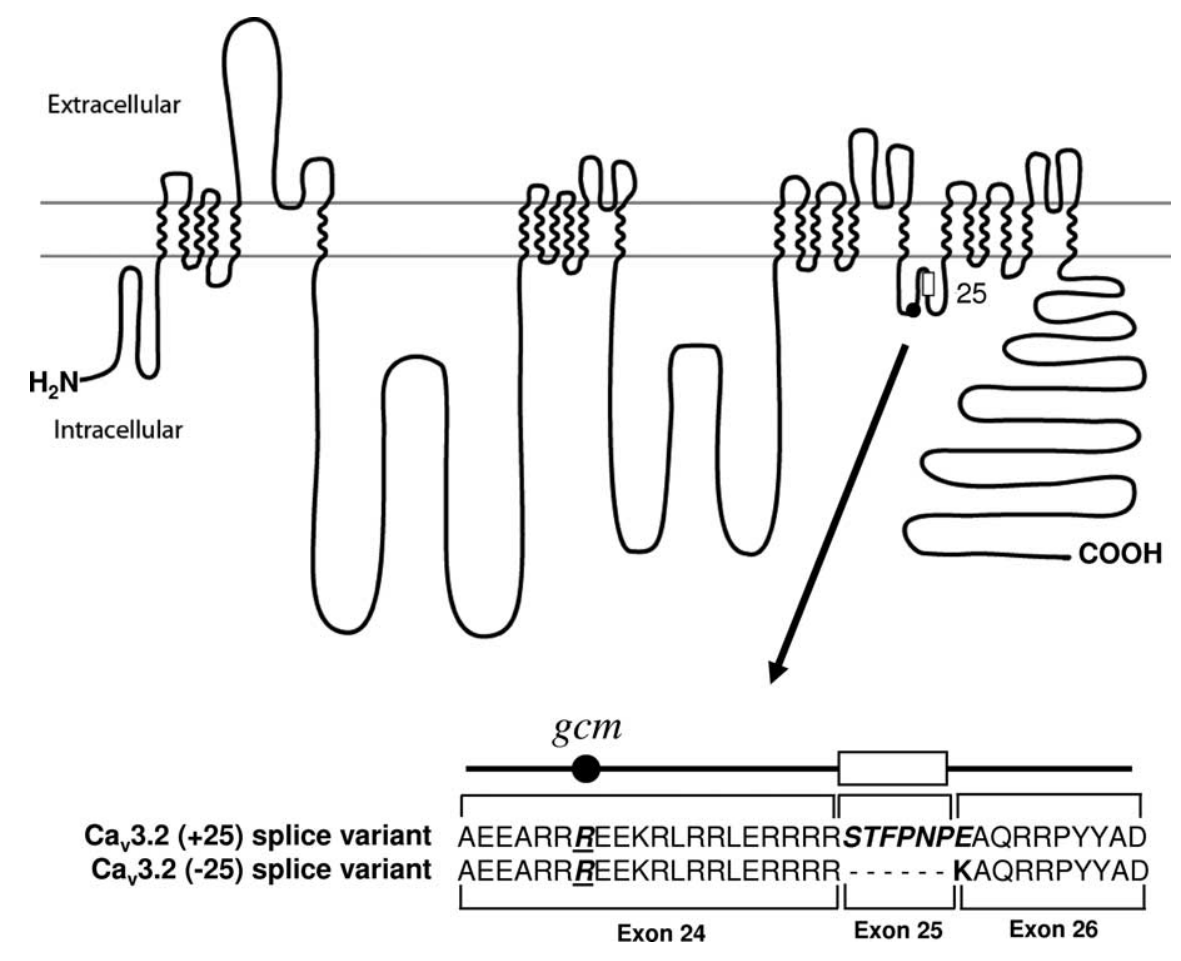

Figure 3. Differential expression of Ca 3.2 splice variants in NEC and GAERS animals. Exon 25 of the rat Cacnath gene is alternatively spliced to produce $\mathrm{Ca}_{\mathrm{v}} 3.2(+25)$ and Cav3.2 ( -25$)$ isoforms. The $\mathrm{Ca}_{\mathrm{v}} 3.2(-25)$ variant channels have a lysine residue at position 1598. This lysine residue is replaced by the 7 aa sequence (STFPNPE) in the $\mathrm{Ca}_{\mathrm{v}} 3.2(+25)$ variant. The R1584P mutation ( $\mathrm{gcm}$ ) site is located 13 aa upstream of the beginning of exon 25 region (underlined arginine residue).

account for variation in current magnitude between cells to yield a charge transference factor $(\mathrm{Q} / \mathrm{pA})$.

\section{Results \\ GAERS possess a mutation in the $\mathrm{Ca}_{\mathrm{v}} 3.2 \mathrm{~T}$-type calcium channel gene}

The entire coding region (7098 bp) of Cacnal $h$ was sequenced in both GAERS $(n=3)$ and NEC $(n=3)$ rats, and we identified a single-nucleotide mutation in GAERS compared with NEC and Rattus norvegicus strains (Table 1). At base pair 4751 in exon 24, NEC rats and $R$. norvegicus both possess a guanine $(G)$, whereas GAERS possess a cytosine (C). The base change results in an amino acid change from an arginine (CGG) to a proline (CCG) at position 1584 (R1584P) located within the domain III-IV linker region of the channel. This region of the gene is highly conserved across species and across other T-type $\mathrm{Ca}^{2+}$ channels, suggesting a critical functional role. Arginine is a basic amino acid with a long side chain, whereas proline is a cyclic amino acid lacking a hydrogen at the amino end and is unable to form hydrogen bonds and thus can disrupt protein structure. Exon 24, the location of the $\mathrm{gcm}$, was then sequenced in another 15 NEC and 22 GAERS, revealing that all NEC rats were null for the $\mathrm{gcm}$ and all GAERS had two copies of the $\mathrm{gcm}$. We screened additional rat strains, i.e., Sprague Dawley, Wistar-Kyoto, spontaneously hypertensive rats, normotensive rats, and WAG/Rij (Wistar Albino Glaxo from Rijswijk; another genetic rat model of absence epilepsy), as well as mouse strains (BALB/c and DBA), and found that none of these carry any copies of the R1584P mutation. NEC rats (which originate from a Wistar strain) and R. norvegicus (Brown Norway) also do not carry any copies of the R1584P mutation.
The $\mathrm{gcm}$ positively correlates with the epileptic phenotype in GAERS

The epileptic phenotype that was attributable to the $\mathrm{gcm}$ was assessed in the progeny of an F1 cross between GAERS and NEC rats. Homozygous animals carrying either two copies of the $\mathrm{gcm}$ or null for the $\mathrm{gcm}$ were compared for the total amount of time spent in seizures during a 90 min EEG recording and also for the number, duration, and frequency of the seizures. Examples of EEG traces from an animal null for the $\mathrm{gcm}$ are shown in Figure 1, $a$ and $d$, from an animal heterozygous for the $\mathrm{gcm}$ in Figure $1, b$ and $e$, and an animal homozygous for the $\mathrm{gcm}$ in Figure 1, $c$ and $f$. More F2 animals possessing two copies of the $\mathrm{gcm}(92.5 \% ; n=12)$ express seizures than animals possessing zero $(50 \% ; n=8)$ or one copy $(66.7 \% ; n=24)$ of the $\mathrm{gcm}$ ( $p=0.058 ; \mathrm{m} / \mathrm{m}$ vs $+/+$; Fisher's exact test, one tailed). A strong $g \mathrm{~cm}$ dose effect is evident for the time spent in seizure activity, with animals homozygous for the $\mathrm{gcm}$ spending significantly more time in seizure activity than animals null for the $\mathrm{gcm}$ $(3.1 \pm 1.5 \%, n=12$ vs $0.5 \pm 0.4 \%, n=8$; $p<0.05$ ) (Fig. 2a). A significant association between the presence of the $\mathrm{gcm}$ and the number of seizures was also seen (Fig. $2 b$ ). Animals homozygous for the mutation experienced $38.5 \pm 13.6(n=12)$ seizures compared with $10.5 \pm 8.1(n=8)$ seizures for animals null for the mutation $(p<0.05)$. Additionally, animals homozygous for the mutation had a significantly shorter interval between the seizures than animals null for the mutation $(268.1 \pm 5364.8 \mathrm{~s}$, $n=12$ vs $4048.5 \pm 5321.9$ s, $n=8 ; p<0.05$ ) (Fig. $2 c$ ). The length of the individual seizures did not significantly differ between the three genotypes (zero copies, $3.01 \pm 0.95 \mathrm{~s}, n=4$; one copy, $3.03 \pm 0.7 \mathrm{~s}, n=16$; two copies, $3.1 \pm 0.87 \mathrm{~s}, n=11 ; p>0.05$ null vs homozygous) (Fig. 2d). The cycle frequency (hertz) of the spike-and-wave discharges accompanying the seizures was also not affected by the $\mathrm{gcm}$. Animals null for the mutation had a seizure frequency of $7.7 \pm 0.2 \mathrm{~Hz}$, and animals homozygous for the mutation had a seizure frequency of $7.6 \pm 0.2 \mathrm{~Hz}(p>0.05)$ (Fig. 2e). Only animals that had seizures were included in the seizure duration and cycle frequency analysis.

Although our results provide evidence that the $\mathrm{gcm}$ plays a significant role in the absence epilepsy phenotype, they also demonstrate that the mutation does not, by itself, account for the entire phenotype. Some of the rats that were null for the $\mathrm{gcm}$ displayed absence seizures but significantly less often than those with the mutation. Similarly, there were rats that were positive for the $\mathrm{gcm}$ that either did not experience any (1 of 12) or experienced very few ( 2 of 12 ) absence seizures during the recording period. This is consistent with the current hypothesis that the determinants of the absence seizures in patients with IGE are polygenic (Crunelli and Leresche, 2002; Rudolf et al., 2004). A nonparametric Spearman's rank order correlation test was performed to examine the strength of the association between the number of copies of the $\mathrm{gcm}$ mutation in the F2 animals with their various seizure endpoints. A significant correlation was found for the percentage time in seizures $(r=0.31, p=0.04)$ and the 
number of seizures occurring during the recording period $(r=0.34, p=0.02)$. No significant correlation existed for the average length of the individual seizures $(r=$ $-0.17, p=0.35$ ) or for the cycle frequency (hertz) of the spike-and-wave discharges $(r=0.12, p=0.52)$.

\section{Different splice variants of Cacnalh are expressed in the rat thalamus}

We identified two major thalamic splice variants of the rat Cacnalh that differ with respect to the presence or absence of exon 25. $\mathrm{Ca}_{\mathrm{v}} 3.2(+25)$ transcripts include exon 25, whereas $\mathrm{Ca}_{\mathrm{v}} 3.2(-25)$ transcripts exclude exon 25 (Fig. 3). We hypothesized that there may be a splice-variant-specific effect of $\mathrm{gcm}$ in $(+25)$ versus $(-25)$ because the $\mathrm{gcm}$ mutation is situated in the adjacent exon 24 , only 13 aa upstream of the beginning of exon 25 region (Fig. $3 a$ ). The inclusion of exon 25 results in an insertion of $18 \mathrm{nt}$ ( $6 \mathrm{aa}$ ) plus the substitution of a lysine to a glutamate at the beginning of exon 26. Examination of adult Wistar full-length thalamic cDNA clones screened for splice variation $(n=76)$ showed approximately equal proportions of both splice variants $\left[\mathrm{Ca}_{\mathrm{v}} 3.2(+25)=\right.$ $51 \%$ and $\mathrm{Ca}_{\mathrm{v}} 3.2(-25)=48 \%$ of the total pool of $\mathrm{Ca}_{\mathrm{v}} 3.2$ channels; data not shown]. Quantitative real-time-PCR analysis of the thalamus from $>13$-week-old NEC ( $n=$ $7)$ and GAERS $(n=7)$ animals revealed that there was no significant difference in the relative copy number of $\mathrm{Ca}_{\mathrm{v}} 3.2$ mRNA $\left[\mathrm{Ca}_{\mathrm{v}} 3.2(+25)+\mathrm{Ca}_{\mathrm{v}} 3.2(-25)\right]$ between NEC and GAERS animals (NEC, $178.2 \pm$ 23.4, $n=7$; GAERS, $123.4 \pm 19.8, n=7$; $p=0.09)$. However, the ratio of $\mathrm{Ca}_{\mathrm{v}} 3.2$ $(+25)$ to $\mathrm{Ca}_{\mathrm{v}} 3.2(-25)$ splice variants was $\sim 1.5$-fold greater in GAERS animals compared with the NEC strain [NEC, $\mathrm{Ca}_{\mathrm{v}} 3.2$ $(+25) / \mathrm{Ca}_{\mathrm{v}} 3.2(-25)=0.91 \pm 0.06, n=7$; GAERS, $\mathrm{Ca}_{\mathrm{v}} 3.2(+25) / \mathrm{Ca}_{\mathrm{v}} 3.2(-25)=$ $1.51 \pm 0.11, n=7 ; p<0.0001]$.

\section{The $\mathrm{gcm}$ results in a splice-variant-} specific gain of function effect on $\mathrm{Ca}_{\mathrm{v}} 3.2$ (+25)-containing channels

$\mathrm{Ca}_{\mathrm{v}} 3.2$ channel function was assessed electrophysiologically in vitro using HEK293 cells transiently expressing either the $\mathrm{Ca}_{\mathrm{v}} 3.2(+25)$ or the $\mathrm{Ca}_{\mathrm{v}} 3.2(-25)$ splice variant \pm the $\mathrm{gcm}$. The $\mathrm{gcm}$ had no significant effect on activation and inactivation kinetics, conductance, or steady-state inactivation of $\mathrm{Ca}_{\mathrm{v}} 3.2$ channels in either splice variant (Fig. $4 a, b$, Table 2 ). The $g \mathrm{~cm}$ also had no significant effect on the current density of either variant (Table 2). However, the $\mathrm{gcm}$ induced a splice-variant-specific gain of function in $\mathrm{Ca}_{\mathrm{v}} 3.2$ $(+25)$ biophysical properties that could be highly relevant to neuronal burst firing. $\mathrm{Ca}_{\mathrm{v}} 3.2(+25) \mathrm{gcm}$ channels recovered from an inactivating prepulse at a significantly faster rate (smaller slow

\section{b}

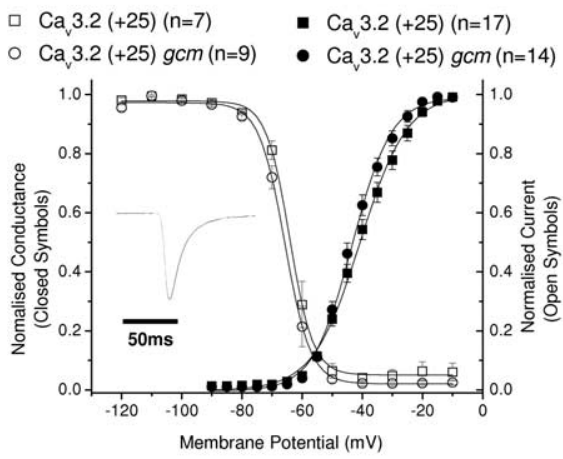

든 $\mathrm{Ca}_{\mathrm{v}} 3.2(-25)(\mathrm{n}=7)$

- Ca $3.2(-25)(n=10)$

- Ca $3.2(-25) \mathrm{gcm}(\mathrm{n}=8)$

- Ca $3.2(-25) \mathrm{gcm}(\mathrm{n}=16)$

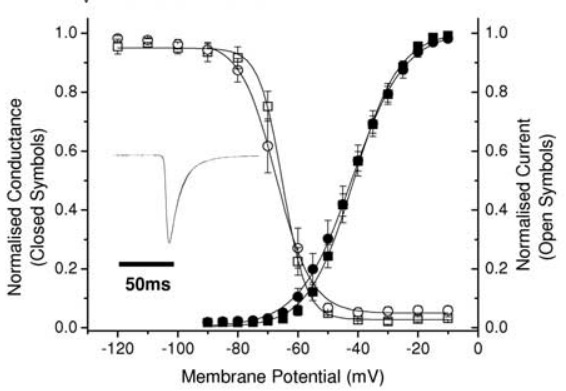

C

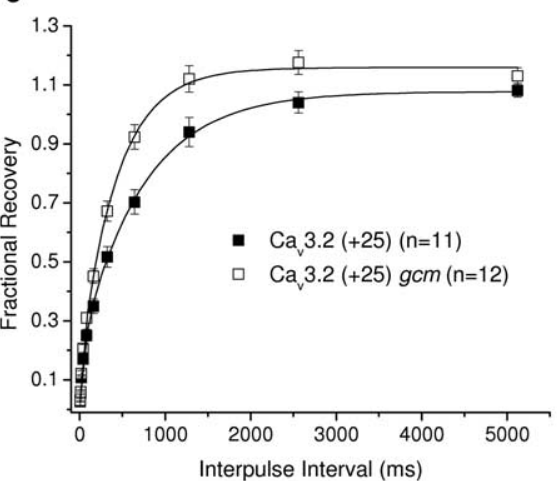

d

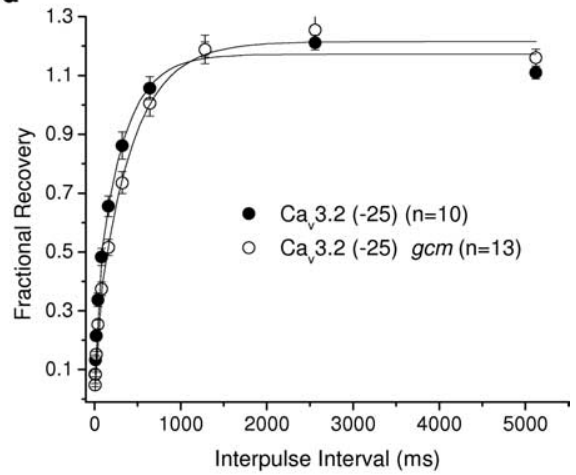

f

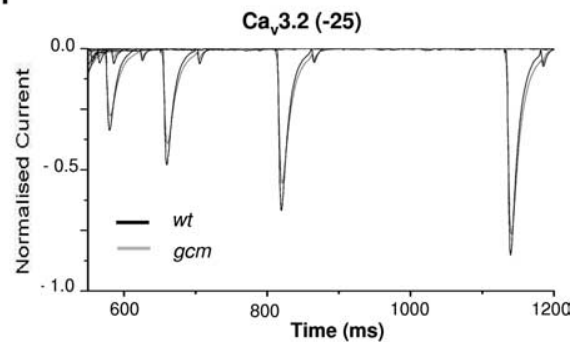

Figure 4. The $g \mathrm{~cm}$ accelerates rate of recovery from inactivation in the $C \mathrm{a}_{\mathrm{v}} 3.2(+25)$ splice variant. $\boldsymbol{a}, \boldsymbol{b}$, The conductance (filled symbols) of $\mathrm{Ca}_{\mathrm{v}} 3.2(+25)(\boldsymbol{a})$ and $\left(\mathrm{a}_{\mathrm{v}} 3.2(-25)(\boldsymbol{b})\right.$ and steady-state inactivation (open symbols) of $\mathrm{Ca}_{\mathrm{v}} 3.2(+25)(\boldsymbol{a})$ and $\mathrm{Ca}_{\mathrm{v}} 3.2(-25)(\boldsymbol{b})$ were not significantly altered by the $\mathrm{gcm}$. Insets $(\boldsymbol{a}, \boldsymbol{b})$ show overlaid $\mathrm{gcm}$ and wild-type macroscopic currents during a $150 \mathrm{~ms}$ depolarizing pulse from a holding potential of -110 to $-20 \mathrm{mV}$. Activation and inactivation kinetics of $\mathrm{Ca}_{\mathrm{v}} 3.2$ $(+25)\left(\boldsymbol{a}\right.$, inset) and $\left(\mathrm{a}_{\mathrm{v}} 3.2(-25)\left(\boldsymbol{b}\right.\right.$, inset) splice variant currents are not affected by the $\mathrm{gcm}$. $\mathrm{Ca}_{\mathrm{v}} 3.2$ conductance was calculated from currents recorded during a series of depolarizing steps from a holding potential of $-110 \mathrm{mV}$ to various membrane potentials and normalized to maximum conductance. Steady-state inactivation was calculated from $\mathrm{Ca}_{\mathrm{v}} 3.2$ currents recorded during a test pulse to $-30 \mathrm{mV}$ directly after a 2 s inactivating prepulse of varying membrane potentials and normalized to peak current. $\boldsymbol{c}, \boldsymbol{d}$, The effect of the $\mathrm{g}(\mathrm{cm}$ on fractional recovery (determined by the ratio of the peak current at the test pulse to the peak current at the prepulse and fitted to a double exponential) is shown for $\mathrm{Ca}_{\mathrm{v}} 3.2(+25)(\boldsymbol{c})$ and $\mathrm{Ca}_{\mathrm{v}} 3.2(-25)(\boldsymbol{d})$. C $\mathrm{a}_{\mathrm{v}} 3.2$ currents were recorded during test voltage pulses from a holding potential of -110 to $-30 \mathrm{mV}$ after an inactivating prepulse, with an increasing interpulse interval. $\boldsymbol{e}, \boldsymbol{f}$, Representative traces obtained at test pulses after 160, 320, 640, and 1280 ms interpulse intervals are shown for $\mathrm{Ca}_{\mathrm{v}} 3.2(+25)(\boldsymbol{e})$ and $\mathrm{Ca}_{\mathrm{v}} 3.2(-25)(\boldsymbol{f})$ currents. Normalized $\mathrm{Ca}_{\mathrm{v}} 3.2(+25)$ currents from 80 to $2560 \mathrm{~ms}$ interpulse intervals were significantly increased in the $\mathrm{gcm}[80 \mathrm{~ms}$ : wild type, $0.25 \pm 0.02 ; g \mathrm{~cm}, 0.31 \pm 0.02(p<0.05) ; 160 \mathrm{~ms}$ : wild type, $0.35 \pm 0.02 ; g \mathrm{~cm}, 0.45 \pm 0.02(p<0.01) ; 320 \mathrm{~ms}$ : wild type, $0.52 \pm 0.03 ; g \mathrm{~cm}, 0.67 \pm 0.03(p<0.005) ; 640 \mathrm{~ms}$ : wild type, $0.70 \pm 0.04 ; g \mathrm{~cm}, 0.92 \pm 0.04(p<0.005) ; 1280 \mathrm{~ms}$ : wild type, $0.94 \pm 0.05 ; g \mathrm{~cm}, 1.12 \pm 0.05(p<0.05)$; 2560: wild type, $1.04 \pm 0.04 ; g \mathrm{~cm}, 1.16 \pm 0.04(p<0.05)$; wild type, $n=11 ; g \mathrm{~cm}, n=12]$.

recovery tau; $\tau_{2}$ ) than $\mathrm{Ca}_{\mathrm{v}} 3.2(+25)$ channels (Fig. $4 c$ ). Conversely, the $\mathrm{gcm}$-mediated gain of function was not observed in the $\mathrm{Ca}_{\mathrm{v}} 3.2(-25)$ splice variant, in which the $\mathrm{Ca}_{\mathrm{v}} 3.2(-25) \mathrm{gcm}$ channels had a modestly slower rate of recovery (larger $\tau_{2}$ ) (Fig. $4 d$, Table 2). As the $\mathrm{gcm}$ increases the rate of recovery from inactivation in $\mathrm{Ca}_{\mathrm{v}} 3.2(+25)$, more of these channels are available to conduct during subsequent depolarizations, resulting in significantly larger $\mathrm{Ca}^{2+}$ currents from 80 to $2560 \mathrm{~ms}$ interpulse inter- 
Table 2. Whole-cell conductance, steady-state inactivation, and recovery from inactivation properties of $\mathrm{Ca}_{\mathrm{v}} 3.2$ $( \pm 25)$ splice variants in the presence and absence of the $\mathrm{gcm}$

\begin{tabular}{lrrrr}
\hline Biophysical properties & $\mathrm{Ca}_{\mathrm{v}} 3.2(+25)$ & $\mathrm{Ca}_{\mathrm{v}} 3.2(+25) \mathrm{gcm}$ & $\mathrm{Ca}_{\mathrm{v}} 3.2(-25)$ & $\mathrm{Ca}_{\mathrm{v}} 3.2(-25) \mathrm{gcm}$ \\
\hline Conductance & & & & \\
$\quad V_{50}$ & $-41.2 \pm 1.2$ & $-43.3 \pm 1.0$ & $-41.9 \pm 1.2$ & $-42.6 \pm 2.2$ \\
$\quad k$ & $-7.0 \pm 0.3$ & $-6.0 \pm 0.3$ & $-7.0 \pm 0.4$ & $-7.0 \pm 0.5$ \\
$G_{\max }$ & $7.7 \pm 0.9$ & $8.6 \pm 1.0$ & $9.7 \pm 2.0$ & $7.0 \pm 1.06$ \\
$\quad$ Peak/density (pA/pF) & $-22.3 \pm 3.2$ & $-30.1 \pm 4.4$ & $-19.0 \pm 3.5$ & $-19.4 \pm 3.8$ \\
Steady-state inactivation & & & & \\
$\quad V_{50}$ & $-65.1 \pm 1.2$ & $-66.1 \pm 1.2$ & $-65.2 \pm 1.2$ & $-67.5 \pm 2.3$ \\
$\quad k$ & $3.9 \pm 0.4$ & $4.1 \pm 0.3$ & $3.9 \pm 0.4$ & $4.4 \pm 1.0$ \\
Recovery from inactivation & & & & \\
$\tau_{1}$ & $27.5 \pm 2.1$ & $24.1 \pm 2.5$ & $33.1 \pm 3.8$ & $25.3 \pm 5.7$ \\
$\tau_{2}$ & $745.0 \pm 32.2$ & $436.8 \pm 37.6^{*}$ & $328.5 \pm 35.8$ & $430.5 \pm 25.3^{* *}$ \\
\hline
\end{tabular}

All values were calculated individually for each cell and the mean \pm SEM taken to achieve the stated values (ANOVA; ${ }^{*} p<0.001,{ }^{* *} p<0.05$ compared with wild-type control).
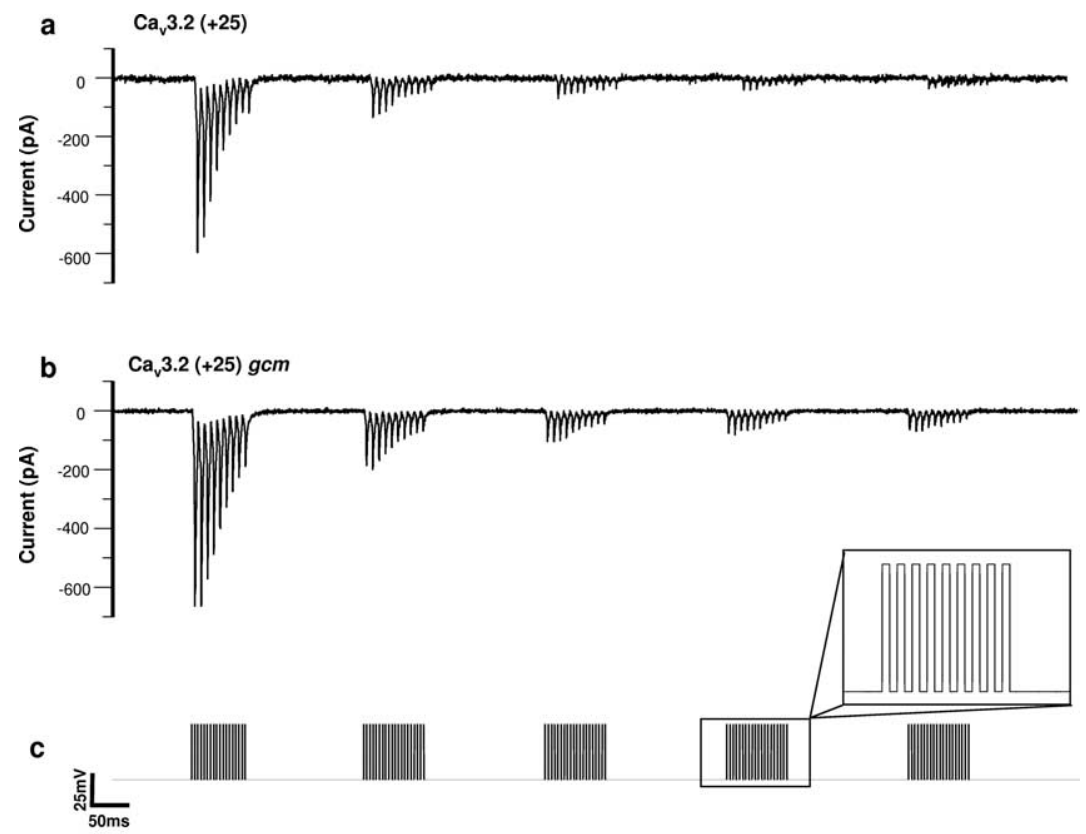

d
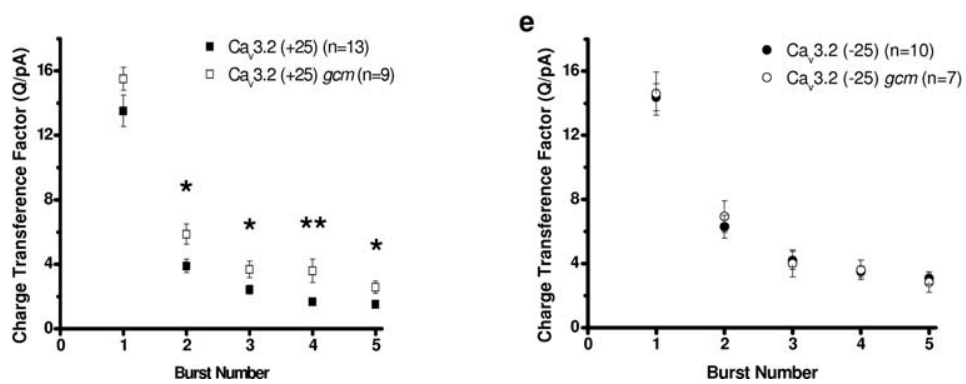

Figure 5. The $g \mathrm{~cm}$ increases the charge transference of $\mathrm{Ca}_{v} 3.2(+25)$ during high-frequency burst depolarizing trains. $\boldsymbol{a}-\boldsymbol{c}$, Representative traces of $\mathrm{Ca}_{\mathrm{v}} 3.2(+25)$ wild-type $(\boldsymbol{a})$ and $\mathrm{Ca}_{\mathrm{v}} 3.2(+25) \mathrm{gcm}(\boldsymbol{b})$ currents recorded during high-frequency depolarizing train pulses ( $125 \mathrm{~Hz}$ for $80 \mathrm{~ms}$ ) from -70 to $-20 \mathrm{mV}$ occurring in bursts ( $5 \mathrm{~Hz}$ for $1 \mathrm{~s}$ ) (c). Charge transference of $\mathrm{Ca}_{\mathrm{v}} 3.2$ during each burst was divided by the peak current on first pulse of the first burst to account for variations in current magnitude. $\boldsymbol{d}$, In $\mathrm{Ca}_{\mathrm{v}} 3.2(+25)$, the $\mathrm{gcm}$ significantly increased the charge transference factor in all subsequent bursts after one $125 \mathrm{~Hz}$ burst. $\boldsymbol{e}$, In $\mathrm{Ca}_{\mathrm{v}} 3.2(-25)$, the $\mathrm{gcm}$ had no significant effect on the charge transference factor. Data are represented as mean \pm SEM. ${ }^{*} p<$ $0.05,{ }^{* *} p<0.01$, significant difference between charge transference factors (ANOVA).

vals (Fig. 4e,f). During multiple depolarizations, this would produce larger $\mathrm{Ca}^{2+}$ currents in cells expressing $\mathrm{Ca}_{\mathrm{v}} 3.2(+25) \mathrm{gcm}$ channels, potentially increasing excitability and promoting epileptogenesis (Contreras, 2006).
To assess the potential effect of the $\mathrm{gcm}$ on the properties of $\mathrm{Ca}_{\mathrm{v}} 3.2( \pm 25)$ splice variants during neuronal burst firing conditions, we designed a voltage waveform that used high-frequency burst depolarizing pulses (Fig. 5, Table 3). Ca $3.2(+25)$ $\mathrm{gcm}$-containing channels generated a significantly greater value for the charge transference factor in all subsequent bursts after one $125 \mathrm{~Hz}$ burst compared with $\mathrm{Ca}_{\mathrm{v}} 3.2(+25)$ channels (Fig. 5d). Conversely, the $\mathrm{gcm}$ had no effect on the charge transference factor during high-frequency bursts in $\mathrm{Ca}_{\mathrm{v}} 3.2(-25)$ channels (Fig. 5 e). The increased charge transference factor observed in $\mathrm{Ca}_{\mathrm{v}} 3.2(+25) \mathrm{gcm}$ channels may be directly related to the increased rate of recovery from inactivation, because a faster recovery from inactivation may lead to an increase in the channels available to conduct on subsequent depolarizations.

\section{Discussion}

Here we report the first genetic abnormality with a functional effect in any of the spontaneously epileptic rat models of absence epilepsy. We identified a mutation in GAERS $(\mathrm{gcm})$ in the rat ortholog of $C A C N A 1 H$, wherein mutations have been identified previously in human absence epilepsy patients (Chen et al., 2003; Liang et al., 2006, 2007; Heron et al., 2007). Examining crosses between NEC and GAERS animals, we found that the presence of the $\mathrm{gcm}$ mutation segregated with seizure expression in the $\mathrm{F} 1$ progeny. These results provide evidence that the $\mathrm{gcm}$ mutation plays a significant role in the absence epilepsy phenotype, but the mutation does not, by itself, account for the entire phenotype. Some rats that were null for the $\mathrm{gcm}$ still displayed absence seizures, albeit significantly less often than those possessing the mutation. Correlation analysis indicated that the presence of $\mathrm{gcm}$ accounted for approximately one-third of the variance for the percentage time in seizures and the number of seizures. These findings are consistent with the current idea that IGE is a polygenic disease (Crunelli and Leresche, 2002; Rudolf et al., 2004; Glasscock et al., 2007). Rudolf et al. (2004) mapped various seizure-related quantitative trait locus (QTL) in GAERS versus Brown Norway rat double crosses to chromosomes 4,7 , and 8 . The relevant genes and genetic mutations within the regions represented by these QTLs have not been identified. Our group has reported an increase in expression of both stargazin mRNA and protein in the cortex and thalamus of GAERS (Powell et al., 2008), the gene for which (Cacng2) lies within the QTL on chromosome 7. However, the genetic 
Table 3. Mean \pm SEM charge transference values for $\mathrm{Ca}_{\mathrm{v}} 3.2( \pm 25)$ splice variants in the presence and absence of the $\mathrm{gcm}$ during high-frequency bursts

\begin{tabular}{|c|c|c|c|c|}
\hline & Charge, $\mathrm{Ca}_{\mathrm{v}} 3.2(+25)$ & Transference, $\mathrm{Ca}_{\mathrm{v}} 3.2(+25) \mathrm{gcm}$ & Factor, $\mathrm{Ca}_{\mathrm{v}} 3.2(-25)$ & $\mathrm{Q} / \mathrm{pA}, \mathrm{Ca}_{\mathrm{v}} 3.2(-25) \mathrm{gcm}$ \\
\hline Burst 1 & $13.5 \pm 1.0$ & $15.5 \pm 0.7$ & $14.4 \pm 0.8$ & $14.6 \pm 1.3$ \\
\hline Burst 2 & $3.9 \pm 0.4$ & $5.9 \pm 0.6^{*}$ & $6.3 \pm 0.7$ & $6.9 \pm 1.0$ \\
\hline Burst 3 & $2.4 \pm 0.3$ & $3.7 \pm 0.5^{*}$ & $4.2 \pm 0.6$ & $4.0 \pm 0.8$ \\
\hline Burst 4 & $1.67 \pm 0.2$ & $3.6 \pm 0.7^{* *}$ & $3.5 \pm 0.4$ & $3.6 \pm 0.6$ \\
\hline Burst 5 & $1.5 \pm 0.2$ & $2.6 \pm 0.4^{*}$ & $3.1 \pm 0.4$ & $2.8 \pm 0.6$ \\
\hline
\end{tabular}

ANOVA, ${ }^{*} p<0.05,{ }^{* *} p<0.01$ compared with wild-type control.

cause for this is still unknown. The Rudolf study failed to identify a QTL on chromosome 10, the location of the $\mathrm{Ca}_{\mathrm{v}} 3.2$ gene, but the primary seizure variables associated with the QTLs in this study were the duration, amplitude, and cycle frequency of the spike-and-wave discharges, which we found were not associated with the $\mathrm{gcm}$ (Fig. 2). The only significant association found with the number of seizures expressed, the variable that we found to be most strongly associated with $\mathrm{gcm}$, was with the QTL on chromosome 7 in 6-month-old (but not 3-month-old) rats. The only other genetic abnormality reported in GAERS is an extra alanine residue in a polyalanine tract in the potassium channel, KCNK9 (Holter et al., 2005). However, no functional consequences of this mutation have been identified in vivo or in vitro.

Our study also identified two major $\mathrm{Ca}_{\mathrm{v}} 3.2$ channel splice variants expressed in the rat thalamus, $\mathrm{Ca}_{\mathrm{v}} 3.2(+25)$ and $\mathrm{Ca}_{\mathrm{v}} 3.2(-25)$, which differ in the presence or absence of the small exon 25. Of particular interest is the finding that the ratio of $\mathrm{Ca}_{\mathrm{v}} 3.2(+25)$ mRNA to $\mathrm{Ca}_{\mathrm{v}} 3.2(-25)$ mRNA is greater in the thalamus of GAERS animals compared with NECs, suggesting that the relative proportion of $\mathrm{Ca}_{\mathrm{v}} 3.2(+25)$ to $\mathrm{Ca}_{\mathrm{v}} 3.2$ $(-25)$ is subjected to transcriptional regulation. Whether the increase in relative expression of the +25 variant in GAERS is a direct effect of $\mathrm{gcm}$ on splicing or an indirect effect on transcription is unknown.

In $\mathrm{Ca}_{\mathrm{v}} 3.2(+25)$ channels transiently expressed in HEK293 cells, the $\mathrm{gcm}$ induces a faster rate of recovery from inactivation, thereby promoting a $\mathrm{Ca}^{2+}$ charge transference of greater magnitude during burst firing conditions. Contrastingly, in $\mathrm{Ca}_{\mathrm{v}} 3.2$ $(-25)$ channels, the $\mathrm{gcm}$ modestly slows recovery and has no effect on charge transference during bursts. It would appear that the $\mathrm{gcm}$ increases the rate of recovery of $\mathrm{Ca}_{\mathrm{v}} 3.2(+25)$ channels to a rate similar to that of channels without the 25 exon segment, $\mathrm{Ca}_{\mathrm{v}} 3.2(-25)$. It is not known whether this is attributable to the separate mechanisms of $\mathrm{gcm}$ and exon 25 acting in opposition or whether the $\mathrm{gcm}$ acts to somehow silence the functional effect of exon 25 inclusion. Whether $\mathrm{Ca}_{\mathrm{v}} 3.2(+25)$ and $\mathrm{Ca}_{\mathrm{v}} 3.2(-25)$ splice variants are expressed selectively or coexpressed in the same cells is also unknown. If the splice variants are coexpressed within cells, there would be an expected heterologous population of both fast ( - exon 25) and slow ( + exon 25$)$ recovering channels in $\mathrm{gcm}+/+$ animals. The occurrence of the $\mathrm{gcm}$ in $\mathrm{m} / \mathrm{m}$ animals would drive all cells expressing $\mathrm{Ca}_{\mathrm{v}} 3.2$ channels to a fast recovering type, which may increase synchrony of neuronal firing. Alternatively, if the splice variants are expressed in a mutually exclusive manner, the $\mathrm{gcm}$ change would be predicted to produce a cell-specific increase in excitability.

T-type $\mathrm{Ca}^{2+}$ channels underlie a low-threshold spike that plays an important role in the generation of oscillatory thalamocortical rhythms and in the switch between tonic and burst firing patterns (Destexhe and Sejnowski, 2002; Contreras, 2006; Joksovic et al., 2006). Increased $\mathrm{Ca}_{\mathrm{v}} 3.2$ expression and increased T-type currents have been detected in the nRT of GAERS and WAG/Rij (Tsakiridou et al., 1995; Talley et al., 2000; Kim et al., 2001; Broicher et al., 2008), suggesting that $\mathrm{Ca}_{\mathrm{v}} 3.2$ channels may be a strong candidate for contribution to SWD generation in the thalamocortical network. This is supported by computational modeling, demonstrating that increased T-type activity has the ability to promote burst firing (Chorev et al., 2006) and that temporal changes in $\mathrm{Ca}_{\mathrm{v}} 3.2$ conductance alone can synchronize oscillations (Huguenard and Prince, 1992). Thus, the larger currents achieved by the $\mathrm{gcm}$ in $\mathrm{Ca}_{\mathrm{v}} 3.2(+25)$ channels during high-frequency bursts alone may be sufficient to induce oscillations. The $\mathrm{gcm}$ might render neurons of the nRT more susceptible to excitatory corticothalamic and thalamocortical inputs, producing more robust bursting activity. However, the net result of increased $\mathrm{Ca}^{2+}$ charge transference during high-frequency bursts is difficult to discern because of the intricacy of the neuronal network involved. In addition, although it may seem logical that the $\mathrm{gcm}$ would increase the duration of seizure activity attributable to longer-lasting $\mathrm{Ca}^{2+}$ conductance during burst firing, there is no direct evidence as yet to confirm that $\mathrm{Ca}_{\mathrm{v}} 3.2$ channels are the molecular pacemaker controlling bursting. Aside from any direct biophysical effects of the mutation on excitability, it is also possible that increased $\mathrm{Ca}^{2+}$ entry might enhance $\mathrm{Ca}^{2+}$ signaling, with the potential to alter gene expression (Rudolf et al., 2004). $\mathrm{Ca}^{2+}$ as a signaling molecule has numerous cellular effects and $\mathrm{Ca}_{\mathrm{v}} 3.2$ channels, for example, are known to induce increased expression of high-voltageactivated $\mathrm{Ca}^{2+}$ channels and to induce neuritogenesis (Chemin et al., 2002).

The expression of different splice variants is now recognized as an important mechanism by which the diversity of cellular effects required for normal functions in different tissues and cell types is achieved. Splice variation in the $\mathrm{Ca}_{\mathrm{v}} 3.1$ and $\mathrm{Ca}_{\mathrm{v}} 3.3 \mathrm{~T}$-type $\mathrm{Ca}^{2+}$ channels has also been shown to alter electrophysiological properties and provides a general molecular mechanism for the functional diversity of T-type $\mathrm{Ca}^{2+}$ channels (Mittman et al., 1999a,b; Monteil et al., 2000; Chemin et al., 2001; Murbartián et al., 2002, 2004). Genetic mutations that have physiological effects only in selected splice variants may be an important mechanism by which some disease-causing mutations exhibit their well defined temporal and spatial phenotypes (Adams et al., 2007). As previously noted, alternative splicing of exon 26 in the human $\mathrm{Ca}_{\mathrm{v}} 3.2$ gene (corresponding to the rat exon 25) alters the rate of recovery from inactivation (Ohkubo et al., 2005; Zhong et al., 2006). Our findings show that modification of rat exon 25 by the upstream $\mathrm{gcm}$ in $\mathrm{Ca}_{\mathrm{v}} 3.2( \pm 25)$ splice variants can also alter the rate of recovery from inactivation. Thus, the III-IV linker region of $\mathrm{Ca}_{\mathrm{v}} 3.2$ appears to be critically involved in the recovery from inactivation of T-type channels, potentially modulating the stability of the inactivated state. Consistent with our findings, there is also evidence that the III-IV linker region of 
$\mathrm{Ca}_{\mathrm{v}} 3.1$ channels contributes to T-type channel inactivation (Chemin et al., 2001; Staes et al., 2001).

Overall, the results of our study emphasize that the effects of missense mutations and the effects of alternative splicing on ion channel function must be considered together. Missense mutations that produce little or no direct changes in channel function may nevertheless interfere with regulatory sequences and lead to aberrant splicing, especially if, as found in the human $\mathrm{Ca}_{\mathrm{v}} 3.2$ gene, some of the mutations flank splicing junctions (Liu et al., 2001; Zhong et al., 2006). Zhong et al. (2006) have described the splice variations in the human $\mathrm{Ca}_{\mathrm{v}} 3.2$ gene and characterized their effects electrophysiologically (Zhong et al., 2006). Importantly, they demonstrated the interdependency of the effect of these variants. Our study extends this further to demonstrate that T-type channel mutations can have measurable functional effects in only certain splice variants. This provides a mechanism by which genetic mutations could produce spatial and temporal cell-typespecific effects dependent on splice variant expression patterns. This concept has potentially important implications for the pathophysiology of the IGEs wherein mild perturbations in the balance of activity between interconnected neuronal networks results in an epileptic phenotype but otherwise retains normal neurological functioning. It may also help explain both why somatic genetic mutations have been observed to result in seizures arising exclusively from topographically restricted focal brain regions (Fukata et al., 2006).

\section{References}

Adams PJ, Garcia E, Snutch TP, Spacey SD (2007) Splice variant composition of P/Q-type calcium channels affects both biophysical properties and sensitivity to an FHM point mutation. Biophys J Abstr 2869:602A.

Broicher T, Kanyshkova T, Meuth P, Pape HC, Budde T (2008) Correlation of T-channel coding gene expression, IT, and the low threshold $\mathrm{Ca}^{2+}$ spike in the thalamus of a rat model of absence epilepsy. Mol Cell Neurosci 39:384-399.

Carbone E, Lux HD (1984) A low voltage-activated, fully inactivating Ca channel in vertebrate sensory neurones. Nature 310:501-502.

Chemin J, Monteil A, Bourinet E, Nargeot J, Lory P (2001) Alternatively spliced $\alpha_{1 \mathrm{G}}\left(\mathrm{Ca}_{\mathrm{V}} 3.1\right)$ intracellular loops promote specific T-type $\mathrm{Ca}^{2+}$ channel gating properties. Biophys J 80:1238-1250.

Chemin J, Nargeot J, Lory P (2002) Neuronal T-type $\alpha_{1 \mathrm{H}}$ calcium channels induce neuritogenesis and expression of high-voltage-activated calcium channels in the NG108-15 cell line. J Neurosci 22:6856-6862.

Chen Y, Lu J, Pan H, Zhang Y, Wu H, Xu K, Liu X, Jiang Y, Bao X, Yao Z, Ding K, Lo WH, Qiang B, Chan P, Shen Y, Wu X (2003) Association between genetic variation of $\mathrm{CACNA} 1 \mathrm{H}$ and childhood absence epilepsy. Ann Neurol 54:239-243.

Chorev E, Manor Y, Yarom Y (2006) Density is destiny. On the relation between quantity of T-type $\mathrm{Ca}^{2+}$ channels and neuronal electrical behavior. CNS Neurol Disord Drug Targets 5:655-662.

Contreras D (2006) The role of T-channels in the generation of thalamocortical rhythms. CNS Neurol Disord Drug Targets 5:571-585.

Crunelli V, Leresche N (2002) Childhood absence epilepsy: genes, channels, neurons and networks. Nat Rev Neurosci 3:371-382.

Destexhe A, Sejnowski TJ (2002) The initiation of bursts in thalamic neurons and the cortical control of thalamic sensitivity. Philos Trans R Soc Lond B Biol Sci 357:1649-1657.

Fukata Y, Adesnik H, Iwanaga T, Bredt DS, Nicoll RA, Fukata M (2006) Epilepsy-related ligand/receptor complex LGI1 and ADAM22 regulate synaptic transmission. Science 313:1792-1795.

Glasscock E, Qian J, Yoo JW, Noebels JL (2007) Masking epilepsy by combining two epilepsy genes. Nat Neurosci 10:1554-1558.

Heron SE, Khosravani H, Varela D, Bladen C, Williams TC, Newman MR, Scheffer IE, Berkovic SF, Mulley JC, Zamponi GW (2007) Extended spectrum of idiopathic generalized epilepsies associated with $\mathrm{CACNA1H}$ functional variants. Ann Neurol 62:560-568.

Holter J, Carter D, Leresche N, Crunelli V, Vincent P (2005) A TASK3 chan- nel (KCNK9) mutation in a genetic model of absence epilepsy. J Mol Neurosci 25:37-51.

Huguenard JR, Prince DA (1992) A novel T-type current underlies prolonged $\mathrm{Ca}^{2+}$-dependent burst firing in GABAergic neurons of rat thalamic reticular nucleus. J Neurosci 12:3804-3817.

Joksovic PM, Nelson MT, Jevtovic-Todorovic V, Patel MK, Perez-Reyes E, Campbell KP, Chen CC, Todorovic SM (2006) Cav3.2 is the major substrate for redox regulation of $\mathrm{T}$-type $\mathrm{Ca}^{2+}$ channels in the rat heart and mouse thalamus. J Physiol 574:415-430.

Khosravani H, Altier C, Simms B, Hamming KS, Snutch TP, Mezeyova J, McRory JE, Zamponi GW (2004) Gating effects of mutations in the Cav3.2 T-type calcium channel associated with childhood absence epilepsy. J Biol Chem 279:9681-9684.

Khosravani H, Bladen C, Parker DB, Snutch TP, McRory JE, Zamponi GW (2005) Effects of Cav3.2 channel mutations linked to idiopathic generalized epilepsy. Ann Neurol 57:745-749.

Kim D, Song I, Keum S, Lee T, Jeong MJ, Kim SS, McEnery MW, Shin HS (2001) Lack of the burst firing of thalamocortical relay neurons and resistance to absence seizures in mice lacking $\alpha_{1 \mathrm{G}}$ T-type $\mathrm{Ca}^{2+}$ channels. Neuron 31:35-45.

Liang J, Zhang Y, Wang J, Pan H, Wu H, Xu K, Liu X, Jiang Y, Shen Y, Wu X (2006) New variants in the CACNA1H gene identified in childhood absence epilepsy. Neurosci Lett 406:27-32.

Liang J, Zhang Y, Chen Y, Wang J, Pan H, Wu H, Xu K, Liu X, Jiang Y, Shen $\mathrm{Y}, \mathrm{Wu}$ X (2007) Common polymorphisms in the CACNA1H gene associated with childhood absence epilepsy in Chinese Han population. Ann Hum Genet 71:325-335.

Liu HX, Cartegni L, Zhang MQ, Krainer AR (2001) A mechanism for exon skipping caused by nonsense or missense mutations in BRCA1 and other genes. Nat Genet 27:55-58.

Liu L, Zheng T, Morris MJ, Wallengren C, Clarke AL, Reid CA, Petrou S, O’Brien TJ (2006) The mechanism of carbamazepine aggravation of absence seizures. J Pharmacol Exp Ther 319:790-798.

Llinás R, Yarom Y (1981) Electrophysiology of mammalian inferior olivary neurones in vitro. Different types of voltage-dependent ionic conductances. J Physiol 315:549-567.

Marescaux C, Micheletti G, Vergnes M, Depaulis A, Rumbach L, Warter JM (1984) A model of chronic spontaneous petit mal-like seizures in the rat: comparison with pentylenetetrazol-induced seizures. Epilepsia 25:326-331.

Marescaux C, Vergnes M, Depaulis A (1992) Genetic absence epilepsy in rats from Strasbourg: a review. J Neural Transm Suppl 35:37-69.

Mattson RH (2003) Overview: idiopathic generalized epilepsies. Epilepsia 44 [Suppl 2]:2-6.

Mittman S, Guo J, Emerick MC, Agnew WS (1999a) Structure and alternative splicing of the gene encoding alpha1I, a human brain $\mathrm{T}$ calcium channel alphal subunit. Neurosci Lett 269:121-124.

Mittman S, Guo J, Agnew WS (1999b) Structure and alternative splicing of the gene encoding alpha1G, a human brain $\mathrm{T}$ calcium channel alphal subunit. Neurosci Lett 274:143-146.

Monteil A, Chemin J, Bourinet E, Mennessier G, Lory P, Nargeot J (2000) Molecular and functional properties of the human $\alpha_{1 \mathrm{G}}$ subunit that forms T-type calcium channels. J Biol Chem 275:6090-6100.

Murbartián J, Arias JM, Lee JH, Gomora JC, Perez-Reyes E (2002) Alternative splicing of the rat $\mathrm{Ca}_{\mathrm{v}} 3.3 \mathrm{~T}$-type calcium channel gene produces variants with distinct functional properties(1). FEBS Lett 528:272-278.

Murbartián J, Arias JM, Perez-Reyes E (2004) Functional impact of alternative splicing of human T-type Cav3.3 calcium channels. J Neurophysiol 92:3399-3407.

Ohkubo T, Inoue Y, Kawarabayashi T, Kitamura K (2005) Identification and electrophysiological characteristics of isoforms of T-type calcium channel $\mathrm{Ca}_{\mathrm{v}} 3.2$ expressed in pregnant human uterus. Cell Physiol Biochem 16:245-254.

Peloquin JB, Khosravani H, Barr W, Bladen C, Evans R, Mezeyova J, Parker D, Snutch TP, McRory JE, Zamponi GW (2006) Functional analysis of Ca3.2 T-type calcium channel mutations linked to childhood absence epilepsy. Epilepsia 47:655-658.

Perez-Reyes E (2003) Molecular physiology of low-voltage-activated t-type calcium channels. Physiol Rev 83:117-161.

Powell KL, Kyi M, Reid CA, Paradiso L, D’Abaco GM, Kaye AH, Foote SJ, O’Brien TJ (2008) Genetic absence epilepsy rats from Strasbourg have 
increased corticothalamic expression of stargazin. Neurobiol Dis 31:261-265.

Rudolf G, Thérèse Bihoreau M, F Godfrey R, P Wilder S, D Cox R, Lathrop M, Marescaux C, Gauguier D (2004) Polygenic control of idiopathic generalized epilepsy phenotypes in the genetic absence rats from Strasbourg (GAERS). Epilepsia 45:301-308.

Staes M, Talavera K, Klugbauer N, Prenen J, Lacinova L, Droogmans G, Hofmann F, Nilius B (2001) The amino side of the C-terminus determines fast inactivation of the T-type calcium channel alpha1G. J Physiol 530:35-45.

Talley EM, Solórzano G, Depaulis A, Perez-Reyes E, Bayliss DA (2000) Lowvoltage-activated calcium channel subunit expression in a genetic model of absence epilepsy in the rat. Brain Res Mol Brain Res 75:159-165.

Tsakiridou E, Bertollini L, de Curtis M, Avanzini G, Pape HC (1995) Selective increase in T-type calcium conductance of reticular thalamic neurons in a rat model of absence epilepsy. J Neurosci 15:3110-3117.
Vitko I, Chen Y, Arias JM, Shen Y, Wu XR, Perez-Reyes E (2005) Functional characterization and neuronal modeling of the effects of childhood absence epilepsy variants of CACNA1H, a T-type calcium channel. J Neurosci 25:4844-4855.

Vitko I, Bidaud I, Arias JM, Mezghrani A, Lory P, Perez-Reyes E (2007) The I-II loop controls plasma membrane expression and gating of $\mathrm{Ca}_{\mathrm{v}} 3.2$ T-type $\mathrm{Ca}^{2+}$ channels: a paradigm for childhood absence epilepsy mutations. J Neurosci 27:322-330.

Zhang Y, Vilaythong AP, Yoshor D, Noebels JL (2004) Elevated thalamic low-voltage-activated currents precede the onset of absence epilepsy in the SNAP25-deficient mouse mutant coloboma. J Neurosci 24:5239-5248.

Zhong X, Liu JR, Kyle JW, Hanck DA, Agnew WS (2006) A profile of alternative RNA splicing and transcript variation of CACNA1H, a human $\mathrm{T}$-channel gene candidate for idiopathic generalized epilepsies. Hum Mol Genet 15:1497-1512. 